\title{
COMMENTS
}

\section{The Relevant Market Concept in Conspiracy to Monopolize Cases under Section 2 of the Sherman Act}

Section 2 of the Sherman Act prohibits monopolization and attempts and conspiracies to monopolize. In actual and attempted monopolization cases the prevailing rule requires the plaintiff to prove that the defendant has acted with the specific intent to monopolize the relevant market. A number of courts, however, have viewed market definition as irrelevant in section 2 conspiracy cases. This comment examines the relevant market requirement in conspiracy to monopolize cases. It argues that in light of the law of actual and attempted monopolization the rationales for dispensing with the relevant market concept in section 2 conspiracy cases are unpersuasive. The comment concludes by elucidating the practical consequences of requiring proof of intent to preempt the relevant market in section 2 conspiracy cases.

\section{The Role of Market Definition in Actual and Attempted Monopolization Cases}

The offense of actual monopolization consists of the possession of monopoly power, defined as "the power to control prices or exclude competition," coupled with "willful acquisition or maintenance of that power as distinguished from growth or development as a consequence of a superior product, business acumen, or historical accident." 3 The defendant must be shown to possess a significant share of the business done in the relevant market." Thus, in

\footnotetext{
' Section 2 of the Sherman Act, 15 U.S.C. $\$ 2$ (Supp. IV 1974) provides:

Every person who shall monopolize, or attempt to monopolize, or combine or conspire with any other person or persons, to monopolize any part of the trade or commerce among the several States, or with foreign nations, shall be deemed guilty of a felony, and on conviction thereof, shall be punished by fine not exceeding one million dollars if a corporation, or, if any other person, one hundred thousand dollars, or by imprisonment not exceeding three years, or by both said punishments, in the discretion of the court.

2 United States v. E.I. du Pont de Nemours \& Co., 351 U.S. 377, 391 (1956).

3 United States v. Grinnell Corp., 384 U.S. 563, 570-71 (1966).

- The percentage of market control which will be considered equivalent to monopoly power differs with the type of market involved. The cases, however, suggest that control of $80 \%$ or more of the relevant market will in itself suffice to prove that a firm possesses monopoly power. See, e.g., American Tobacco Co. v. United States, 328 U.S. 781, 797 (1946) (80\% market share constitutes monopoly power); Kansas City Star Co. v. United States, 240 F.2d 643 (8th Cir. 1957) (95\%); United States v. Aluminum Co. of America, 148 F.2d 416 (2d
} 
actual monopolization cases definition of the relevant market is essential to the plaintiff's proof that the defendant possesses monopoly power. ${ }^{5}$

The first authoritative statement of the elements of the attempted monopolization offense was given by Justice Holmes in Swift \& Co. v. United States. ${ }^{6}$ Attempted monopolization, he stated, consists of business conduct creating "a dangerous probability" that actual monopolization will ensue, undertaken with a specific intent to monopolize. ${ }^{7}$ The subsequent history of section 2 attempt law is comprised largely of lower court efforts to give meaning to the Swift formula. The dangerous probability requirement does not raise particularly difficult problems of definition. ${ }^{8}$ Most courts require the plaintiff to show that the defendant's conduct resulted in its acquisition of market control dangerously proximate to monopoly power. ${ }^{9}$ The content of the intent requirement, on the

Cir. 1945) (90\%). On the other hand, control of less than $50 \%$ is often considered conclusive evidence of the absence of monopoly power. See, e.g., United States v. United Shoe Machinery Corp., 110 F. Supp. 295, 346 (D. Mass. 1953), aff'd per curiam, 347 U.S. 521 (1954) (50\% or smaller share insufficient); Kershaw v. Kershaw Mfg. Co., 209 F. Supp. 447, 454 (M.D. Ala. 1962), aff'd per curiam, 327 F.2d 1002 (5th Cir. 1964) (7.2\% insufficient).

s See United States v. Grinnell Corp., 384 U.S. 563, 570-71 (1966); Independent Iron Works, Inc. v. United States Steel Corp., 322 F.2d 656, 667 (9th Cir.), cert. denied, 375 U.S. 922 (1963); Joe Westbrook, Inc. v. Chrysler Corp., 419 F. Supp. 824, 845 (N.D. Ga. 1976).

Despite the fact that market definition is primarily a factual determination, the plaintiff may be required adequately to allege a relevant market. See Tire Sales Corp. v. Cities Service Oil Corp., 410 F. Supp. 1222, 1231 (N.D. Ill. 1976).

6 196 U.S. 375 (1905).

7 Id. at 396.

* The proximity requirement has been criticized principally on the ground that the focus on proximity allows much anticompetitive conduct to escape antitrust condemnation. See, e.g., Note, Prosecutions for Attempt to Monopolize: The Relevance of the Relevant Market, 42 N.Y.U. L. Rev. 110 (1967); Note, Attempt to Monopolize: The Offense Redefined, 1969 UTAH L. Rev. 704.

Several courts have apparently accepted this argument and have omitted the dangerous proximity requirement or ignored market dimensions altogether. See, e.g., Lessig v. Tidewater Oil Co., 327 F.2d 459, $474-75$ (9th Cir.), cert. denied, 377 U.S. 993 (1964); Union Carbide \& Carbon Corp. v. Nisley, 300 F.2d 561, 586 (10th Cir. 1961); Rea v. Ford Motor Co., 355 F. Supp. 842, 876-78 (W.D. Pa. 1973); rev'd on other grounds, 497 F.2d 577 (3d Cir.), cert. denied, 419 U.S. 868 (1974); Mount Lebanon Motors, Inc. v. Chrysler Corp., 283 F. Supp. 453, 461 (W.D. Pa. 1968), aff'd per curiam, 417 F.2d 622 (3d Cir. 1969).

- See, e.g., Acme Precision Prods., Inc. v. American Alloys Corp., 484 F.2d 1237, 1240 41 (8th Cir. 1973); Cornwell Quality Tools Co. v. C.T.S. Co., 446 F.2d 825, 833 (9th.Cir. 1971), cert. denied, 404 U.S. 1049 (1972); Joe Westbrook, Inc. v. Chrysler Corp., 419 F. Supp. 824, 844 (N.D. Ga. 1976); Tire Sales Corp. v. Cities Service Oil Co., 410 F. Supp. 1222, 1230-31 (N.D. Ill. 1976); Diamond Int'l Corp. v. Walterhoefer, 289 F. Supp. 550, 578 (D. Md. 1968). But see Union Carbide \& Carbon Corp. v. Nisley, 300 F.2d 561, 586 (10th Cir. 1961); Rea v. Ford Motor Co., 355 F. Supp. 842, 876-78 (W.D. Pa. 1973), rev'd on other grounds, 497 F.2d (3d Cir.), cert. denied, 419 U.S. 868 (1974); Mount Lebanon Motors, Inc. v. Chrysler Corp., 283 F. Supp. 453, 461 (W.D. Pa. 1968), aff'd per curiam, 417 F.2d 622 (3d Cir. 1969). Although the Third Circuit reversed the district court decision in Rea on other grounds, it indicated in 
other hand, has been the subject of some controversy, for specific intent to monopolize seems to be a nebulous concept lacking any referent in the real world. ${ }^{10}$ The intent requirement is generally not satisfied by a showing of intent to exclude a single competitor." The predominant view requires the plaintiff to show that the defendant intended to preempt competition in a relevant product and geographic market. ${ }^{12}$

Market definition in attempted monopolization cases serves several important functions. First, and most obviously, delineation of the market and computation of the defendant's market share serve to determine the proximity issue..$^{13}$ Second, market evidence plays an important role in the determination whether the defendant in fact schemed to monopolize. The defendant may be able to rebut any inference of scheme to monopolize if its market share is miniscule. ${ }^{11}$ Third, market evidence can support a defense one court has termed "legal impossibility": even though the defendant may have formed some plan to exclude certain competitors, attempt liability will not attach if the relevant market is sufficiently broad that success in the endeavor would not constitute the completed offense of monopolization. ${ }^{15}$ Since the objective proscribed by section 2 , as the

dictum that market evidence is relevant in attempt cases and that dangerous probability of success is an element of the offense. 497 F.2d at 590 n.28.

10 The intent requirement has been attacked as fictive since a finding of specific intent to monopolize is sometimes simply tantamount to the conclusion that the defendant's conduct has had anticompetitive consequences not outweighed by a legitimate business purpose. See generally Hawk, Attempts to Monopolize-Specific Intent as Antitrust's Ghost in the Machine, 58 CORNELL L. REv. 1121 (1973).

"See, e.g., Mackay v. Sears, Roebuck \& Co., 237 F.2d 869, 873 (7th Cir. 1956); Keco Indus., Inc. v. Borg-Warner Corp., 334 F. Supp. 1240, 1245.46 (M.D. Pa. 1971); Bender v. Hearst Corp., 152 F. Supp. 569, 578 (D. Conn. 1957), aff'd on other grounds, 263 F.2d 360 (2d Cir. 1959).

12 See, e.g., Coleman Motor Co. v. Chrysler Corp., 525 F.2d 1338, 1348 (3d Cir. 1975); Acme Precision Prods., Inc. v. American Alloys Corp., 484 F.2d 1237, 1240 (8th Cir. 1973); Agrashell, Inc. v. Hammons Prods. Co., 479 F.2d 269, 284 (8th Cir.), cert. denied, 414 U.S. 1022 (1973); Cornwell Quality Tools Co. v. C.T.S. Co., 446 F.2d 825, 833 (9th Cir. 1971); cert. denied, 404 U.S. 1049 (1972); Bernard Food Indus., Inc. v. Dietene Co., 415 F.2d 1279, 1284 (7th Cir. 1969), cert. denied, 397 U.S. 912 (1970); American Football League v. National Football League, 323 F.2d 124, 132 n.18 (4th Cir. 1963); Joe Westbrook, Inc. v. Chrysler Corp., 419 F. Supp. 824, 844 (N.D. Ga. 1976); Tire Sales Corp. v. Cities Service Oil Co., 410 F. Supp. 1222, 1230-31 (N.D. Ill. 1976); 'Diamond Int'l Corp. v. Walterhoefer, 289 F. Supp. 550, 576-77 (D. Md. 1968). But see Rea v. Ford Motor Co., 355 F. Supp. 842, 876-78 (W.D. Pa. 1972), rev'd on other grounds, 497 F.2d 577 (3d Cir.), cert. denied, 419 U.S. 868 (1974) (market evidence not necessary for proof of specific intent to monopolize).

is See cases cited note 9 supra.

14 See, e.g., Hudson Valley Asbestos Corp. v. Tougher Heating \& Plumbing Co., 510 F.2d 1140, 1144 (2d Cir.), cert. denied, 421 U.S. 1011 (1975) (unlikelihood of success evidentiary of absence of monopolistic intent).

is In Bowen v. New York News, Inc., 366 F. Supp. 651 (S.D.N.Y. 1973), the court declared that the plaintiff had the burden of showing "a specific intent to effect a consequence 
Supreme Court stated in the Cellophane case, is the acquisition of "the power to control prices or exclude competition,"16 the intent to achieve a competitive position that does not confer such power should not be unlawful.

\section{The Role of Market Definition in Conspiracy to Monopolize CASES}

The courts have reached conflicting results concerning the role of market definition in section 2 conspiracy cases. A number of courts have ruled that the plaintiff need not prove an intent to monopolize the relevant market. ${ }^{17}$ Several district ${ }^{18}$ and circuit courts, ${ }^{19}$ however, have rejected this view. Part A of this section will examine the three principal rationales advanced by those courts that have rejected market analysis in conspiracy cases. Part B will discuss a possible fourth rationale not clearly articulated in the case law.

\section{A. The Rationales for Dispensing With Market Definition in Conspiracy Cases: A Critique}

1. Argument from the language of section 2. Section 2 of the

definable as monopolizing." Id. at 673. The court stated: "This situation is characterized as legal (as opposed to factual) impossibility. Thus, where the taking of a particular object would not be larceny, the attempt to do so cannot be attempted larceny." Id. at 673 n.51.

${ }_{16}$ United States v. E.I. du Pont de Nemours \& Co., 351 U.S. 377, 391 (1956).

17 See, e.g., United States v. Consolidated Laundries Corp., 291 F.2d 563, 573 (2d Cir. 1961); United States v. National City Lines, Inc., 186 F.2d 562, 573 (7th Cir.), cert. denied, 341 U.S. 916 (1951); Tire Sales Corp. v. Cities Service Oil Co., 410 F. Supp. 1222, 1231-32 (N.D. Ill. 1976); Coleman Motor Co. v. Chrysler Corp., 376 F. Supp. 546, 562 (W.D. Pa. 1974), vacated on other grounds, 525 F.2d 1338 (3d Cir. 1975); Bowen v. New York News, Inc., 366 F. Supp. 651 (S.D.N.Y. 1973); Mount Lebanon Motors, Inc. v. Chrysler Corp., 283 F. Supp. 453, 461 (W.D. Pa. 1968), aff'd per curiam, 417 F.2d 622 (3d Cir. 1969). Dicta in other cases suggest that market evidence is irrelevant in $\S 2$ conspiracy cases. United States v. E.I. du Pont de Nemours \& Co., 351 U.S. 377, 395 n.23 (1956); Salco Corp. v. General Motors Corp., 517 F.2d 567, 576 (10th Cir. 1975); Lessig v. Tidewater Oil Co., 327 F.2d 459, 474 (9th Cir.), cert. denied, 377 U.S. 993 (1964); Harlem River Consumers Coop. v. Associated Grocers, 408 F. Supp. 1251, 1285 (S.D.N.Y. 1976).

Ix See, e.g., Joe Westbrook, Inc. v. Chrysler Corp., 419 F. Supp. 824, 844-45 (N.D. Ga. 1976); Advance Business Sys. \& Supply Co. v. S.C.M. Corp., 287 F. Supp. 143, 153 (D. Md. 1968), aff'd on other grounds, 415 F.2d 55 (4th Cir. 1969), cert. denied, 397 U.S. 920 (1970); United States v. Johns-Manville Corp., 231 F. Supp. 690, $699-700$ (E.D. Pa. 1963); United States v. Huck Mfg. Co., 214 F. Supp. 776, 777-78 (E.D. Mich. 1963), aff'd per curiam, 382 U.S. 197 (1965). In Tire Sales Corp. v. Cities Service Oil Co., 410 F. Supp. 1222 (N.D. IIl. 1976), the court followed the view that market evidence is irrelevant, but expressed "serious reservations" about the soundness of that view. Id. at 1232.

13 American Football League v. National Football League, 323 F.2d 124, 132 n.18 (4th Cir. 1963); Walker Distrib. Co. v. Lucky Lager Brewing Co., 323 F.2d 1, 9 (9th Cir. 1963), cert. denied, 385 U.S. 976 (1966); Packard Motor Car Co. v. Webster Motor Car Co., 243 F.2d 418, 420 (D.C. Cir. 1957). 
Sherman Act prohibits monopolizations of, as well as attempts and conspiracies to monopolize, "any part" of interstate trade or commerce. ${ }^{20}$ The phrase "any part" of commerce has been interpreted to mean any appreciable amount of commerce. ${ }^{21}$ Some courts have concluded that the relevant market concept is irrelevant in section 2 conspiracy cases because the statute condemns conspiracies to exclude competition from any product market so long as more than a minimal volume of business is affected..$^{22}$

This rationale is wholly unpersuasive. The "any part" language of section 2 is applicable to all three of the enumerated offenses. If the "any part of the trade or commerce" language is held to obviate the need for market definition in section 2 conspiracy cases, a similar conclusion would appear to be compelled for actual or attempted monopolization cases. Proof of the relevant market, however, is today uniformly required in actual monopolization cases and is usually required in attempt cases. ${ }^{23}$ The relevant market requirement derives not from the "any part" language of section 2 but rather from the term "monopolize." Any notion that "monopolization" of a product or products is monopolization within the meaning of section 2 without regard to whether the "monopolization" of the product or products confers the power to control prices was laid to rest in the Cellophane case. ${ }^{24}$ The Supreme Court there stated that "where there are market alternatives that buyers may readily use for their purposes, illegal monopoly does not exist merely because the product said to be monopolized differs from others." 25

2. Argument from the Lack of a Proximity Requirement in Conspiracy Offenses. Several courts that have rejected the relevant

20 See note 1 supra.

${ }^{21}$ See, e.g., United States v. Yellow Cab Co., 332 U.S. 218, 225-26 (1947); Salco Corp. v. General Motors Corp., 517 F.2d 567, 576 (10th Cir. 1975) (dictum); Bowen v. New York News, Inc., 366 F. Supp. 651, 676 (S.D.N.Y. 1973). What constitutes an "appreciable" part of commerce has not been spelled out with any precision in the cases.

22 See, e.g., United States v. Consolidated Laundries Corp., 291 F.2d 563, 573 (2d Cir. 1961); Bowen v. New York News, Inc., 366 F. Supp. 651,676 (S.D.N.Y. 1973). See also Salco Corp. v. General Motors Corp., 517 F.2d 567, 576 (10th Cir. 1975).

${ }^{23}$ See text and notes at notes 4-12 supra. While the appreciable amount of commerce test was invoked in several older actual and attempted monopolization cases, see, e.g., United States v. Yellow Cab Co., 332 U.S. 218 (1947); United States v. National City Lines, Inc., 186 F.2d 562 (7th Cir.), cert. denied, 341 U.S. 916 (1951), it is rarely employed in more recent decisions involving those two offenses except insofar as it is relevant in determining the coverage of the Act. See, e.g., Tire Sales Corp. v. Cities Service Oil Co., 410 F. Supp. 1222, 1231-32 (N.D. Ill. 1976).

${ }^{24}$ United States v. E.I. du Pont de Nemours \& Co., 351 U.S. 377 (1956).

${ }^{25}$ Id. at 394. 
market requirement in conspiracy cases have relied upon the lack of a proximity requirement in conspiracy doctrine ${ }^{26} \mathrm{It}$ is argued that once the requisite intent and agreement have been shown, it is irrelevant that the defendants are incapable of achieving monopoly power because of their insignificant market share. Impossibility of success, it is claimed, is not a defense since the gravamen of the offense is illegal intent.

In Bowen v. New York News, Inc. ${ }^{27}$ this reasoning led a district court to utilize different views of the market in evaluating section 2 attempt and conspiracy claims. In Bowen thirty independent home delivery dealers of the New York Daily News, a daily newspaper, sued the publisher and its franchised dealers, alleging, inter alia, that the defendants had attempted and conspired to monopolize through their distribution practices. The publishing company had initiated a franchise system' using carrier boys to make deliveries. The franchise contract contained a limitation on home delivery price of the papers, and defendants prevented independant dealers from acquiring copies of the paper if they refused to join the franchise operation. ${ }^{28}$ The court rejected the plaintiff's contention that, for the purposes of the attempted monopolization charge, the Daily News constituted a market unto itself, and held that the relevant market was the newspaper home delivery market in New York City. With the market thus defined, defendant's market share fell well below the proximity threshhold, and, the court held, the attempt charge was not established. Nonetheless, the court awarded judgment for the plaintiffs on the conspiracy charge. It reasoned that proof of a conspiracy to eliminate intrabrand competition is equivalent to a showing of a conspiracy to monopolize. In the district court's opinion, market analysis was immaterial since specific intent to monopolize was the gravamen of the charge and proximity to success was not at issue..$^{29}$

The difficulty with the Bowen rationale is that it overlooks other functions of market evidence beyond that of establishing proximity to success. Market evidence in attempt cases is relevant also to the issue of specific intent. In Bowen the court ignored the possibility that the insignificance of the defendant's market share might

${ }^{26}$ United States v. Consolidated Laundries Corp., 291 F.2d 563, 573 (2d Cir. 1961); Bowen v. New York News, Inc., 366 F. Supp. 651, 676 (S.D.N.Y. 1973); Mount Lebanon Motors, Inc. v. Chrysler Corp., 283 F. Supp. 453, 461 (W.D. Pa. 1968), aff'd per curiam, 417 F.2d 622 (3rd Cir. 1969).

${ }^{27} 366$ F. Supp. 651 (S.D.N.Y. 1973).

${ }_{2 *}$ These arrangements were held per se violations of $\S 1$. Id. at 672-73.

${ }^{23}$ Id. at 676. 
have been highly germane to the issue of intent to monopolize. If defendant's market strength is minimal, the inherent unlikelihood of success might suggest the unlikelihood of a scheme to monopolize. ${ }^{30}$ Market evidence, moreover, is essential to definition of the illegal objective. The question in every case is whether the conduct alleged is part of a larger scheme to effectuate a consequence characterizable as monopolizing. ${ }^{31}$ The intent to preempt the market for home delivery of the Daily News satisfies the intent requirement of section 2 conspiracy only if the Daily News home delivery market constitutes the relevant market; if it does not, the intent to exclude competition from that market contemplates a result lawful in itself, for competitors remain free to enter the relevant market. The conduct of the publishers thus can be defended against the conspiracy charge on grounds akin to the criminal defense of legal impossibility. In finding against the defendants on the conspiracy count, the court in Bowen did not consider the breadth of the market as evidence bearing on the intent issue.

3. The Argument that Market Evidence Is Unnecessary Since Intent Is Readily Inferred from Conduct. The third rationale for dispensing with market evidence in conspiracy cases is that market evidence is not needed to prove or disprove unlawful intent since conspiracies to monopolize are invariably accompanied by predatory conduct. ${ }^{32}$ The difficulty with this rationale is that the presence of predatory practices does not necessarily indicate a scheme to monopolize. Several courts have held that mere exclusion of, ${ }^{33}$ or refusal to deal with, ${ }^{34}$ a single firm does not in itself show intent to

${ }^{30}$ See, e.g., Hudson Valley Asbestos Corp. v. Tougher Heating \& Plumbing Co., 510 F.2d 1140 (2d Cir. 1974), cert. denied, 421 U.S. 1011 (1975) (inherent unlikelihood of success evidences absence of intent to monopolize).

"See text and notes at notes 15-16 supra.

32 The leading proponent of this view is Professor Turner. See Turner, Antitrust Policy and the Cellophane Case, 70 HARv. L. REv. 281, 305-07 (1956). The Ninth Circuit has held that specific intent to monopolize in $\$ 2$ attempt and conspiracy cases "must be accompanied by predatory conduct directed toward accomplishing the unlawful purpose." Hallmark Indus. v. Reynolds Metals Co., 489 F.2d 8, 12 (9th Cir. 1973). Only the Ninth Circuit seems to require predatory conduct as an element of $\S 2$ attempt and conspiracy. It is not entirely clear what kinds of conduct will be considered predatory, but the Ninth Circuit decisions contemplate inquiry into whether the practices alleged were "predominantly motivated by legitimate business objectives." Chisholm Bros. Farm Equip. Co. v. International Harvester Co., 498 F.2d 1137, 1145 (9th Cir.), cert. denied, 419 U.S. 1023 (1974). This inquiry would seem to exhaust $\S 2$ conspiracy analysis under the Ninth Circuit's view if an agreement can be shown; it is difficult to imagine a hypothetical case in which predatory conduct, but not a conspiracy to monopolize, would be found.

${ }^{23}$ See text and note at note 11 supra.

${ }^{34}$ E.g., Walker Distrib. Co. v. Lucky Lager Brewing Co., 323 F.2d 1, 8-9 (9th Cir. 1963), cert. denied, 385 U.S. 976 (1966); Ace Beer Distribs., Inc. v. Kohn, Inc., 318 F.2d 283, 286-87 
monopolize, even though such conduct can be labeled "predatory." Business behavior may be probative of intent to monopolize, but judges and juries are not justified in drawing inferences about the existence of a scheme to monopolize without considering the dimensions of the market and the defendant market position. As one court has stated, "[a]n agreement might be considered to be calculated to achieve monopoly power when adopted by firms enjoying $80 \%$ of the market, but not when adopted by firms enjoying $10 \%$ of the market." 35

\section{B. An Alternative Rationale: Enforcing Business Ethics}

Notwithstanding that the decisions dispensing with market definition cannot stand on the rationales proffered, they may be defensible on another ground never clearly articulated in the cases. The practical effect of ignoring market context in conspiracy cases is often to impose liability solely because the defendant has engaged in "undesirable" or "unfair" business practices.

For example, in Mount Lebanon Motors, Inc. v. Chrysler Corp., ${ }^{36}$ it was held that a manufacturer's practice of competing unfairly with an independent dealer is actionable under section 2. The plaintiff in Mount Lebanon, an independent auto dealer, alleged that Chrysler and its dealers had monopolized, and, in the alternative, attempted and conspired to monopolize the new Dodge automobile market in Allegheny County, Pennsylvania. Specifically, the manufacturer was charged with competing unfairly at the retail level by subsidizing factory dealers. The Court rejected the plaintiff's argument that the relevant market consisted of new Dodge automobiles in Allegheny County, finding instead that the

(6th Cir.), cert. denied, 375 U.S. 922 (1963); Packard Motor Car Co. v. Webster Motor Car Co., 243 F.2d 418, 420 (D.C. Cir. 1957); Eastcoast Equip. Co. v. Harnischfeger Corp., 354 F. Supp. 335, 341-42 (E.D. Pa. 1973); Carbon Steel Prods. Corp. v. Alan Wood Steel Co., 289 F. Supp. 584 (S.D.N.Y. 1968); South End Oil Co. v. Texaco, Inc., 237 F. Supp. 650, 654-55 (N.D. Ill. 1965). But cf. Industrial Bldg. Materials, Inc. v. Interchemical Corp., 437 F.2d 1336 (9th Cir. 1970) (manufacturer's unfair competition at retail level with distributor with purpose to drive latter from business held to state $\S 1$ and $\S 2$ attempt causes of action).

Termination of dealerships or refusal to supply may violate $\S 2$ where the supplier is a monopolist. Eastman Kodak Co. v. Southern Photo Materials Co., 273 U.S. 359 (1927) (termination of supply to existing distributor). See also Poller v. Columbia Broadcasting Sys., Inc., 368 U.S. 464 (1962) (network cancelled affiliation with plaintiff thereby achieving monopoly in local UHF television market). The Supreme Court has extended the Kodak doctrine to condemn a monopolist's refusal to supply a would-be distributor. Otter Tail Power Co. v. United States, 410 U.S. 366 (1973).

${ }^{33}$ United States v. Huck Mfg. Co., 214 F. Supp. 776, 778 (E.D. Mich. 1963), aff'd per curiam, 382 U.S. 197 (1965).

${ }^{38} 283$ F. Supp. 453 (W.D. Pa. 1968), aff'd per curiam, 417 F.2d 622 (3rd Cir. 1969). 
relevant market included the products of other major auto manufacturers. The court then concluded that the defendants could not effectively raise prices or exclude competition in the relevant market by engaging in the activities alleged in the complaint and granted a directed verdict for the defendants on the actual monopolization charge ${ }^{37}$ However, the court held that a jury question was presented by the allegations that the defendants had attempted and conspired to monopolize. Since specific intent to monopolize is the gravamen of attempt and conspiracy liability, the court reasoned, the possibility or impossibility of success is immaterial. ${ }^{38}$ The implication of the court's holding is that section 2 inchoate offenses are essentially aimed at punishing "unfair" practices regardless of whether those practices might conduce to monopolization.

Such decisions would be unobjectionable if section 2 conspiracy is viewed as a catchall cause of action designed to remedy any exclusionary or otherwise undesirable practice. Professor Turner has expressed a similar view, arguing that in attempt cases, as well as in conspiracy cases, proximity to monopoly power should not be required, on the ground that anticompetitive conduct deserves section 2 punishment regardless of the market strength of the predator firm. ${ }^{39}$ Under this view, section 2 attempt would be available to attack single-firm conduct largely immune from the prohibitions of section 1 because of that section's concerted action requirement. It may be that the term "monopolize" in section 2 conveys meanings other than monopolization in a purely economic sense. Any effort to maintain or augment one's share of the market entails pro tanto exclusion of competitors, and thus perhaps could be viewed as an effort to monopolize. Although it is well established that possession of a large share of the market is requisite to actual monopolization liability, ${ }^{40}$ it would not be wholly unreasonable, as a matter of first impression, to interpret the proscription of inchoate monopolization to reach exclusionary practices regardless of whether the actor intends to achieve a true monopoly position.

However, once the catchall interpretation of section 2 attempt is rejected-and it appears that most courts have rejected it ${ }^{41}$-it is not justifiable to view the conspiracy offense as anything but an incipient attempt involving more than one party. The rejection of

\footnotetext{
${ }^{37} I d$. at 461.

${ }^{3 \times}$ Id. at 462 .

3) Turner, supra note 32 , at 307.

so See note 4 supra.

"See cases cited note 12 supra.
} 
the market concept in section 2 conspiracy cases is inconsistent with the emerging consensus that attempt liability does not attach to "unfair" practices alone. Furthermore, the major justification for the Turner view is that section 2, under such an interpretation, could be employed to reach practices of an individual competitor that cannot be reached by section 1. Many of the single-firm practices at present outside the prohibition of the antitrust laws-such as predatory price-cutting, coercive refusals to sell, and pricefixing-are per se violations of section 1 if they involve concerted action by two or more firms. This justification disappears in section 2 conspiracy, for conspiracy cases by definition involve two or more parties. No additional protection is gained by imposing section 2 conspiracy liability for practices remediable under section 1 .

\section{The Consequences of Using the Relevant Market Concept in Section 2 Conspiracy Cases}

In the majority of cases it appears that the section 2 conspiracy count is unnecessary to the plaintiff's treble damages claim since the conduct alleged would, if proved, amount to a per se restraint of trade under section $1 .{ }^{42}$ For example, many section 2 conspiracy cases involve dealership terminations or refusals to deal. It is well settled that when a refusal to deal is coercive of a vertical restraint, section 1 has been violated. ${ }^{43}$ In such cases, imposition of the relevant market requirement would not affect the determination of liability."

In some cases the practices involved are not per se violations,

${ }^{12}$ In Bowen v. New York News, Inc., 366 F. Supp. 651 (S.D.N.Y. 1973), discussed in text and notes at notes 27-29 supra, for example, imposition of the relevant market requirement under the $\S 2$ conspiracy count would not have affected the issue of the publisher's liability since the publisher's refusal to deal was intended to coerce the retail dealers' acquiescence in a resale price restriction, a per se restraint under $\S 1$. Other cases where rejection of the relevant market concept was not essential to finding Sherman Act liability include: Lessig v. Tidewater Oil Co., 327 F.2d 459 (9th Cir.), cert. denied, 377 U.S. 993 (1964) (termination and threatened termination of contracts of dealers not observing suggested retail prices); United States v. Consolidated Laundries Corp., 291 F.2d 563, 572-73 (2d Cir. 1961) (concerted action to drive out of business independent suppliers who refused to join in scheme of customer allocation, itself a per se restraint).

${ }^{13}$ In United States v. Parke, Davis \& Co., 362 U.S. 29 (1960), the Supreme Court held that the general principle, announced in United States v. Colgate \& Co., 250 U.S. 300 (1919), that sellers may unilaterally refuse to deal absent monopolistic purpose, does not protect refusals to deal coercive of a vertical restraint of trade.

"In criminal cases, however, multiple punishments may be imposed if the defendant violates both $\S 1$ and $\S 2$. See, e.g., American Tobacco Co. v. United States, 147 F.2d 93, 116-17 (6th Cir. 1944), aff'd, 328 U.S. 781 (1946); Shapiro v. King, 125 F.2d 890, 892 (8th Cir. 1942); United States v. Buchalter, 88 F.2d 625, 628 (2d Cir. 1937), cert. denied, 301 U.S. 708 (1937). 
but the allegations raise a section 1 issue regarding the "reasonableness" of the alleged restraints. ${ }^{45}$ Adoption of the relevant market requirement in section 2 conspiracy law will preclude plaintiffs in such cases from obtaining an "easy" treble damage verdict under a conspiracy to monopolize theory, since they will be compelled to prove their case with market evidence that is also relevant to the section 1 count.

An example of this type of case is Walker Distributing Co. $v$. Lucky Lager Brewing Co. ${ }^{46}$ In Walker Distributing plaintiff's distributorship had been terminated for failure to adhere to Lucky's policy that distributors handle Lucky Lager beer exclusively. Walker sued under sections 1 and 2, alleging both a conspiracy to restrain trade and a conspiracy to monopolize. The court dismissed the section 2 count on the ground that Walker had failed to show that Lucky Lager constituted a market unto itself, but denied Lucky's motion for summary judgment on the section 1 claim, and ruled that the alleged restraint would be tested by the rule of reason. ${ }^{47}$ Under the view that the scope of the market is irrelevant in section 2 conspiracy cases, the section 2 claim would probably have survived summary judgment, and may have succeeded without the introduction of market evidence.

In those cases in which the section 1 claim is not meritorious, imposition of the relevant market requirement might preclude any Sherman Act recovery. United States v. National City Lines, Inc. ${ }^{18}$ illustrates this possibility. The challenged practice in National City Lines involved an arrangement whereby a group of firms operating local transit systems accepted financing from a group of firms that supplied buses, bus accessories, tires, and lubricants. In return for the financing the operating firms executed contracts obligating them to purchase their requirements of buses and other supplies from the financing firms. Although defendants were acquitted of all section 1 charges, the arrangement was held a conspiracy to monopolize the sale of supplies used by the local transit systems. On appeal, the defendants claimed that the section 2 convictions should be set aside because the sale of supplies to the operating firms did

is Where the practice in question does not fall within one of the categories of per se restraints, the "rule of reason" is employed to determine the legality of the restraint. The complaining party must demonstrate that the anticompetitive effect of the restraint outweighs the business justification for its use, See Continental T.V., Inc. v. G.T.E. Sylvania, Inc., 97 S. Ct. 2549 (1977); Chicago Bd. of Trade v. United States, 246 U.S. 231, 238-39 (1918).

u 323 F.2d 1 (9th Cir. 1963).

"IT Id. at 6-8.

4* 186 F.2d 562 (7th Cir.), cert. denied, 341 U.S. 916 (1951). 
not constitute a relevant market. The convictions were sustained by the Seventh Circuit on the ground that the scope of the market is irrelevant to section 2 conspiracy claims. National City Lines thus presents a situation where the defendants might have avoided antitrust liability had the court acknowledged the relevance of the relevant market concept. ${ }^{49}$

\section{Conclusion}

Market evidence in conspiracy cases serves two fundamental functions. First, the defendants' share of the relevant market may be highly probative on the issue of whether the defendants entertained the requisite specific intent to monopolize. Second, market evidence is essential to definition of the illegal objective; a conspiracy to dominate some part of commerce should not be unlawful if that domination would not confer the power to raise prices or exclude competition.

None of the rationales advanced for ignoring market evidence in section 2 conspiracy actions are persuasive. The view that market definition plays no role in conspiracy cases is justifiable only if the section 2 inchoate offenses are to be turned into catchall causes of action designed to remedy undesirable business practices. Adoption of this view would entail major revisions in attempted monopolization doctrine, revisions most courts have rejected. Conspiracy claims, like attempt claims, should therefore be evaluated against the market setting of the conduct alleged.

Janis L. Harwell

49 In addition to possibly imposing $\S 2$ liability upon defendants whose practices would not be held anticompetitive under $\S 1$, the courts espousing the view that market definition is irrelevant to $\S 2$ conspiracy might be unwittingly laying the basis for a manufacturer's duty to deal with distributors. In no reported case has $\$ 2$ conspiracy liability attached to a nonmonopolist's termination of a distributorship or refusal to supply an independent dealer without more. However, the sole limiting principle is the Colgate doctrine, under which unilateral refusals to deal (or terminations of distributorships) are privileged absent "a purpose to create or maintain a monopoly," United States v. Colgate \& Co., 250 U.S. 300, 307 (1919), provided the refusal is not coercive of a vertical restraint condemned by $\S 1$. United States v. Parke, Davis \& Co., 362 U.S. 29 (1960). On the theory of $\S 2$ conspiracy adopted by courts rejecting market definition, the Colgate privilege should yield, since those courts view the intent to exclude independent distributors as tantamount to an intent to "create or maintain a monopoly." Elimination of distributors, however, does not confer appreciable power to control prices unless the manufacturer is already a monopolist. It is inconveivable that a non-monopolist producer could achieve monopoly power by eliminating independent distributors of its product. Thus, the better approach to testing such conduct in distributorship cases is through "rule of reason" analysis under $\S 1$, unless it can be shown that the manufacturer is in fact a monopolist. 